\author{
Perakende Sektöründe Kampanya Yönetimine Yönelik İş Zekası \\ Uygulamas1 \\ Erdal AKGÜL ${ }^{\mathrm{a}}$, Mutlu Tahsin ÜSTÜNDAĞ ${ }^{\mathrm{b}}$, Mustafa TANRIVERDİ \\ a. Gazi Üniversitesi, Yönetim Bilişim Sistemleri, ANKARA 06500, TÜRKIYE \\ $b^{*}$ Gazi Üniversitesi, Bilgisayar ve Öğretim Teknolojileri Ĕgitimi, ANKARA 06500, TÜRKIYYE \\ ${ }^{c}$ Gazi Üniversitesi, Yönetim Bilişsim Sistemleri , ANKARA 06500, TÜRKIYYE
}

\section{MAKALE BÍLGİSİ}

Alınma: 21.04.2018

Kabul: 09.06.2018

\section{Anahtar Kelimeler: \\ Karar Destek \\ Sistemleri, Power BI, \\ Perakendecilik, İş \\ Zekas1 \\ "Sorumlu Yazar: \\ e-posta: \\ mutlutahsin@gmail.com}

\section{ÖZET}

Bilişim teknolojilerinin ortaya çıkması ile birlikte bilgiye ulaşmak ve bilgiyi elde tutmak kolaylaşmıştır. İşletmelere ait verilerin bilişim teknolojilerinden yararlanılarak analiz edilmesi sonucu daha anlamlı ve kullanışlı hale getirilmesi süreçlerine iş zekası denilmektedir. İşletmelerin pazarlama, kampanya ve karar alma süreçlerinde iş zekası çözümlerinden faydalanmaları çok yararlı olacaktır. Bu makalede, iş zekası kavramı ve iş zekasından yararlanabilmek için gerekli olan altyapı ihtiyaçları incelenmiştir. Yapılan incelemeler sonucunda da perakende sektörüne yönelik örnek bir uygulama geliştirilerek, işletmelerin iş zekası uygulamalarından nasıl yararlanabileceği ve iş zekası kavramının uygulama yapılan sektöre ilişkin katkıları vurgulanmıştır.

DOI: $10.30855 /$ AIS.2018.01.01.02

\title{
Business Intelligence Application For Campaign Magagement In The Retail Sector
}

\section{ARTICLE \\ INFO \\ Received: \\ 21.04.2018 \\ Accepted: \\ 09.06.2018}

\section{Keywords:}

Decision Support

Systems, Power BI,

Retail Selling,

Business Intelligence

\section{"Corresponding}

Authors

e-mail:

mutlutahsin@gmail.com

\section{ABSTRACT}

Access to and retain information has become easier with the emergence of information technology. All of the processes of analyzing the data of the enterprises by using information technologies and making them more meaningful and useful are called business intelligence. It will be very useful for enterprises to benefit from business intelligence solutions in marketing, campaigning and decision-making processes. In this study, business intelligence concept and the required infrastructure for benefiting from business intelligence applications were examined. According to the investigation, a sample application for retail sector was developed as well as how the businesses will benefit from business intelligence applications and its contributions to the applied sectors were emphasized.

DOI: 10.30855/AIS.2018.01.01.02

\section{GIRISS (INTRODUCTION)}




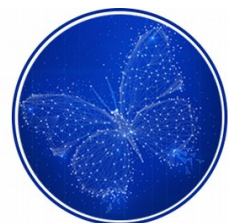

ARTIFICIAL INTELLIGENCE STUDIES

YAPAY ZEKA CCALISYMALARI

www.aistudies.org

Giderek artan ve çeşitlenen tüketici gereksinim ve isteklerine paralel olarak, bilgi ve iletişim teknolojilerindeki hızlı gelişim, pazarlamanın gerçekleştiriliş biçimini ve işletmelerin müşterileri ile ilgili veri ve bilgileri yönetme biçimini değiştirmiştir [1]. Günümüz perakende sektöründe müşteri ihtiyaçlarının doğru analiz edilmesi, hem anlık satışları artırmaya yönelik kampanyaların doğru yönetilmesi hem de tedarik edilecek olan ürünlerin doğru tedarik edilmesi için faydalı olacaktır. Bu nedenle, müşteri ihtiyaçlarının perakendeci firma tarafından önceki alışveriş bilgilerine göre tespit edilebilmesi önemli bir unsur olmuştur [2].

Günümüzde süpermarketlerde kasa yerine kullanılan satıș noktası terminalleri sayesinde satın alma işlemlerinin bütün detayları saklanabilmektedir. Ürün hareketleri ve müşteriler kodlanmışsa her bir müşterinin alışveriş hareketleri tespit edilebilmektedir. Süpermarketlerde veri analizlerinde her ürün için bir sonraki ayın satış tahminleri yapılabilecektir/yapılabilmektedir. Bununla birlikte müşterilerin satın aldıkları ürünlere bağlı olarak gruplandırılması, potansiyel müşterilerin belirlenmesine katkı sağlamaktadır [3].

Bilişim sistemleri genel olarak; verilen bilgileri işleyen, saklayan ve gerekli bilgiye dönüştürerek raporlayabilen sistemlerdir. Pazarlamada satışların takibi, pazar araştırmaları, satış raporlarının hazırlanması, satılan ürün miktarları ve satıcıların elindeki ürün miktarının bilinmesi gibi konularda bilişim sistemlerinden yararlanılmaktadır [4]. Bu süreçte firmaların yapması gereken müşteri ilişsileri yönetimine önem vererek; veri tabanı oluşturmak, pazarlama çabalarını etkin hale getirmek, tüketicilerin alışveriş alışkanlıklarını belirlemek, tüketicilerin istek ve ihtiyaçlarını ve ilgilendikleri alanları belirlemek ve eldeki verileri sürekli yenilemek olmalıdır.

Bilgi teknolojileri araçları sayesinde saklanabilen müşteri ile ilgili veriler, işletmelerin rekabet avantajı elde edebilmesi için önemli firsatlar içermektedir. Bu bağlamda, müşteri bazında detaylı alışveriş bilgilerini saklayan ve karar destek sistemi niteliğinde kullanılan veri ambarı projelerinin firmaların rekabet güçlerini arttırdığını söylemek mümkündür.

$\mathrm{Bu}$ makalede, iş zekası, ilişkili kavramlar ve çeşitli sektörlerdeki iş zekası uygulamaları incelenmiştir. Yapılan incelemeler sonucunda perakende sektörüne yönelik örnek bir uygulama geliştirilerek, işletmelerin iş zekası uygulamalarından nasıl yararlanabileceği ve uygulama yapılan sektöre ilişkin olası katkıları vurgulanmıştır.

\section{KARAR DESTEK SISSTEMLERİ (DECISION SUPPORT SYSTEMS)}

Teknolojinin ilerlemesi ve bilgi temininin kolaylaşması, bu bilgilerden yeni bilgi oluşturulmasını mümkün kılmış, bu bağlamda da "Karar Destek Sistemleri" kavramı ortaya çıkmıştır [5]. Karar destek sistemleri kavramından önce karar verme terimi hakkında bilgi vermek faydalı olacaktır. Literatürde karar verme terimi için birçok tanımlama yapılmaktadır. Bu tanımlamalardan birine göre karar verme, olumlu sonuca ulaşmak için değişik davranışlar arasında etkili olanın seçilmesidir. Diğer bir tanımlamaya göre ise, amaca ulaşmak için seçeneklerin belirlenmesi ve seçenekler içerisinde en etkili olanın seçilmesidir [6].

Karar destek sistemleri (KDS) ise, daha önce gerçekleşmiş olan süreçlerle ilgili eldeki bilgilerden gerekli olanların harmanlanması ile gelecekte gerçekleşmesi muhtemel durumların öngörülerek, alınacak kararların doğruluk payını artıran sistemlerdir. Genel anlamıyla, karar verici konumundaki yöneticilere, strateji belirleme aşamasında destek olan sistemlerdir [7].

KDS kavramı ilk olarak 1960'lı yıllarda ortaya çıkmıştır. M. Scott Morton tarafından 1971'de "Management Decision Systems" (Yönetim Karar Sistemleri) başlıklı bir yazıda incelenmiş ve sonra gerek endüstriyel, gerekse akademik yönden hızla yayılmıştır [8].

KDS'ler, veri tabanındaki modüller aracılığıyla, çok ölçütlü ve birbirleriyle çelişen kriterler altında karar vericinin optimum çözümü elde etmesinde karar vericiye yardımcı olan, problem çözümünü hızlandıran ve kullanıcıyla etkileşimli olarak çalışan bilgisayar destekli sistemler olarak tanımlanabilmektedir. KDS'ler, veri tabanına girilen verileri özetlemede ve analiz etmede karar vericiye yardımcı olmaktadır.

\subsection{KDS'nin Bileşenleri (The Components of Decision Support Systems)}

KDS’ler, veri tabanı, çıkarım mekanizması ve kullanıcı ara yüzünden oluşmaktadır (Şekil 1). 


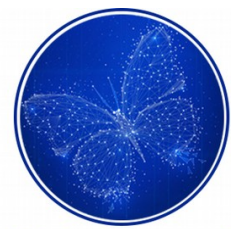

ARTIFICIAL INTELLIGENCE STUDIES

YAPAY ZEKA CCALISYMALARI

2018, 4(1): 8-25

www.aistudies.org

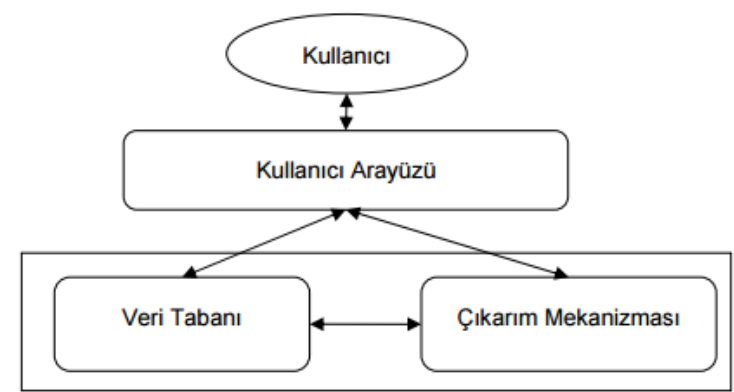

Şekil 1. KDS'nin bileşenleri (The Components of Decision Support Systems)

Veri tabanı problemle ilgili bilgi ve kural cümlelerinden oluşmaktadır. Bir uzmanlık alanıyla ilgili tecrübe ve deneyimler KDS'nin veri tabanına yüklenir ve farklı kaynaklardan elde edilen bilgiler arasındaki ilişkiler kurallarla tanımlanabilir.

Çıkarım mekanizması, model tabanı olarak da adlandırılmaktadır. Karar vericiyi doğru sonuca ulaştıracak olan karar verme, en iyileme, benzetim, tahmin ve analiz modellerinin yer aldığı bölümdür. Bir KDS'nin model tabanında yukarıda belirtilen modellerden sadece biri olabileceği gibi, KDS'nin geliştirilme amacına uygun olarak birden fazla model de model tabanında yer alabilir. Bir modelin çıktısı bir diğer modelin girdisi olarak çalışabilir. Kullanıcı arayüzü ise çıkarım mekanizması, veri tabanı ve kullanıcı arasındaki etkileşimi sağlayan araçtır. Kullanıcı arayüzü gerekli bilginin sisteme girildiği ve sonucun sistemden alındığı ekrandır. Başka bir ifadeyle arayüz, kullanıcı ile KDS arasındaki tüm etkileşimi sağlar. Arayüz tasarımları kullanıcı dostu olmalı ve kullanıcıyı ikileme düşürmeden amacına hizmet etmelidir. Piyasada kullanılan programların çoğu grafiksel arayüze sahip olup ses tanıma özelliği olan arayüz programları da mevcuttur [9].

\subsection{KDS Türleri (Types of Decision Support Systems)}

KDS'ler model, veri, bilgi, grup ve Web tabanlı olmak üzere beş tip olarak sınıflandırılmaktadır.

Model bazlı: Model bazlı KDS'ler, içerisinde istatistik ve optimizasyon gibi modelleri bulunduran karar destek sistemleridir.

Veri bazll: Veri bazlı KDS'ler ise karar vermeyi destekleyecek gerçek zamanlı ve oldukça geniş veri setlerine sahip olan sistemlerdir.

Bilgi bazlı: Bilgi bazlı KDS’ler kural tabanlı sistemler olup kullanıcıya eylemler bildirebilen KDS türleridir.

Grup karar destek sistemleri (GKDS): Birden fazla kullanııının birlikte çalışmasına müsaade edebilen sistemlerdir. Bir başka tanımla, grup karar destek sistemi, ekip çalışmasının etkinliğini artırmak amacıyla KDS ve grup kararı birleştirme yöntemlerini içeren sistemlerdir [8].

Web tabanlı KDS'ler (WKDS): GKDS'lerin gelişmiş modelidir. WKDS'ler farklı lokasyonlarda bulunan karar vericilerin ortak bir ağ aracılığıyla çalışmasını sağlayan ve internetin gelişmesiyle ortaya çıkan KDS'lerdir.

GKDS ve WKDS çalışma prensibi bakımından birbirine benzemekle birlikte aralarındaki önemli fark şudur; GKDS'yi kullanan çalışma ekibi, verileri tek bir platform üzerinde paylaşırken, WKDS'de grup üyeleri problem üzerindeki düşünce ve yargılarını kişisel bilgisayarını kullanarak bir network üzerinde paylaşırlar. GKDS ve WKDS'nin benzer özellikleri ise; her iki KDS'nin de ekip çalışmasına müsaade etmesi ve farklı zaman dilimlerinde bilgi paylaşımını mümkün kılmasıdır [9]. Biz bu çalışmamızda GKDS üzerine yoğunlaşacağız.

Şekil 2'de Karar Destek Sisteminden etkin bir şekilde yararlanabilmek için oluşturulan Karar Destek Sistemi modeli gösterilmektedir. $\mathrm{Bu}$ modele göre içsel ve dışsal kaynaklardan toplanan veriler veri tabanlarına ve yazılım kütüphanelerine çeşitli iş zekası araçları kullanılarak işlenmektedir. Birbirleri ile ilişkilendirilmiş olan bu verilerde çeşitli analizler, sorgulamalar ve raporlamalar gerçekleştirilerek problem ve mevcut durum hakkında bilgiler elde 


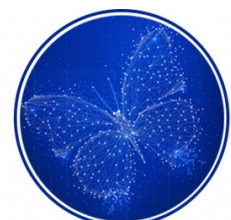

ARTIFICIAL INTELLIGENCE STUDIES

YAPAY ZEKA CCALISYMALARI

edilebilmektedir. Gerçekleştirilen her analiz, sorgulama ve raporlamanın amacı; problemin çözümüne yönelik seçeneklerin ve en olumlu sonuca ulaştırabilecek seçeneğin hangisi olduğuna karar verebilmektir [10].

Elde edilen seçenekler KDS modelinin 4 tasarım aşamasını oluşturmaktadır:

- Araştırma

- Tasarim

- Seçim

- $\quad$ Gözden Geçirme

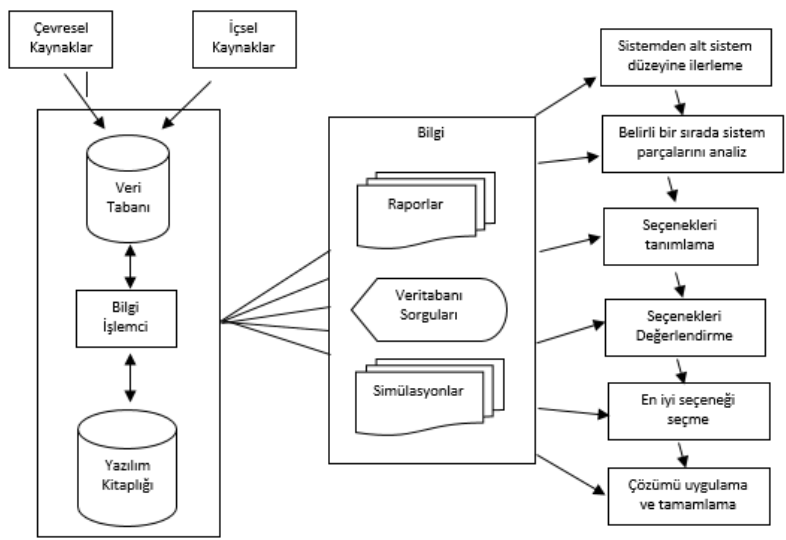

Şekil 2. Karar verme sürecini destekleyen KDS modeli (Decision Support Systems Model Supporting the Decision Process)

Karar Destek Sistemleri'nden yararlanılarak belli iş kuralları içerisinde raporların oluşturulduğu sistemlere İş Zekası denilmektedir. Çeşitli kaynaklardan elde edilen bilgilerin ayıklanarak ve birleştirilerek karar verme süreçlerinde kullanılacak hem detaylı hem de özet bilgiler oluşturulmasını sağlayan sistemlerin genel adı İş Zekası sistemleridir.[11].

\section{3. İS ZEKASI (BUSINESS INTELLIGENCE)}

1940'lı yılların sonuna doğru ortaya çıkan sayısal bilgisayarlar, veri işleme süreçlerinde önemli bir gelişme olarak değerlendirilebilir. İlk yıllarda ağırlıklı olarak veri işleme adı altında bilgi teknolojisi geliştirme çabaları gözlenmektedir. 1970'ler işletmelerde daha karmaşık ihtiyaçlara yönelik yazılım geliştirme çalışmalarının başladığı yıllardır. Bu süreçte geliştirilen yazılımlar Yönetim Bilgi Sistemleri (YBS) olarak adlandırılmaktadır. Bu sistemlerin başlıca amaçları karar vericilerin ihtiyaç duydukları faydalı bilgilere kolay ve zamanında ulaşabilmelerini sağlamak olarak açıklanabilir [12]. 1980'lerin sonuna gelindiğinde grafik ara yüzleri olan kişisel bilgisayarlar ortaya çıkmıştır. Bunun sonucunda veri analizleri yapabilen ve bu analiz sonuçlarını grafiklerle gösterebilme olanağına sahip, çok yönlü etkileşimleri değerlendirebilen uygulamalar ortaya çıkmış ve bilgi işleme faaliyetleri yerel veri tabanları ve elektronik çizelgeler aracılı̆̆ıyla bilgi üretiminde yeni bir dönem başlatmıştır. Bu yeni dönemde geliştirilen ilk uygulamalar günümüzün iş zekası mimarisinin temelleri olarak kabul edilir. 1990'ların sonlarına doğru iş zekası terimi, karar destek sistemlerini ve ham veriyi karar vericilerin ihtiyaç duyduğu faydalı bilgilere dönüștüren analitik model ve yöntemleri içeren mimarileri tanımlamak için kullanılan terim olmuştur. Bu tanımlamadan anlaşılacağı üzere iş zekâsı terimi, hem günlük operasyonel kararların verilmesini kolaylaştıran hem de uzun vadeli kararların bilinçli bir şekilde verilebilmesi için doğru bilgiyi zamanında sorumlu kişilere iletebilen sistemlerin bütünü olarak tanımlanabilir [13].

İş zekası sistemleri, karar vericilere strateji belirleme aşamasında gerekli bilgileri sunabilmek için, bilginin toplandığı, depolandığı ve raporlandığı aşamaların bir araya getirildiği yapılardır. Diğer bir tanımlamaya göre ise; iş zekası sistemleri, toplanan ve harmanlanan bilgilerin süzülerek işletmelerin doğru planlama yapmasına katkı sağlayan sistemlerdir. Her iki tanımda da görülebileceği gibi iş zekası sistemlerinin temel amacı, eldeki verileri birden fazla analitik sistemle faydalı bilgiye dönüştürerek karar vermeye yardımcı olmaktır [11].

1989 yılında Gartner Grubu tarafından ilk kez kullanılmış olan "İş Zekası" terimi, karar vericilerin kararlarını desteklemek için kullanılan araçların iş adımlarını tek çatı altında toplayan süreç olarak kullanılmıştır. İş zekası araçlarının kullanımı, ilk kullanıldığı zamanlardan günümüze kadar giderek artmaktadır.. 


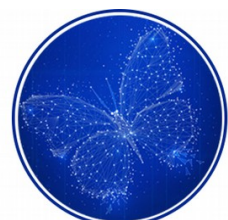

\section{ARTIFICIAL INTELLIGENCE STUDIES \\ YAPAY ZEKA CALISSMALARI \\ 2018, 4(1): 8-25}

İş zekası, karar vericilere destek olmak amacıyla çeşitli ortamlardan alınmış olan ham verilerin tek bir çatı altında toplanarak çeşitli yöntemlerle analiz edilmesi, gereksiz olanların temizlenmesi, sorgular ve raporlar aracilığıyla tekrar anlamlı hale getirilmesi gibi süreçleri içerisinde barındırmaktadır.

Şekil 3'te, farklı konseptlerin nasıl bir araya getirilerek iş hayatında kullanılabilecek raporlar haline getirildiği Gartner Grubu tarafından hazırlanan, "fonksiyonel yakınsaklık" (functional convergence) şeması ile görselleștirilmiştir [14].

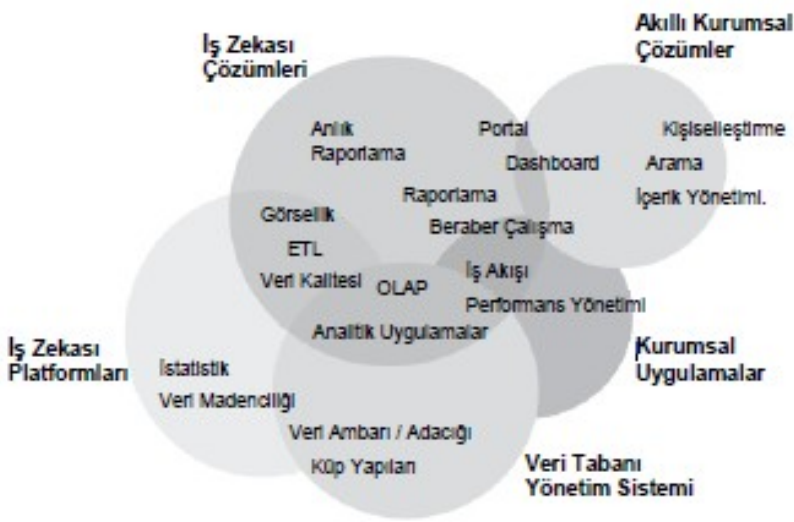

Şekil 3. İş Zekası ve ilgili konseptlerin fonksiyonel yakınsaklık şeması (Functional Schema of the Closeness About Business Intelligence and Conceptions)

İş zekası kavramını özetlemek gerekirse; işletmeler ilk olarak elde edilen verinin kaybedilmemesi amacıyla veri ambarlarını oluşturur, ardından belli entegrasyon yazılımları ile veri ambarındaki verilere ulaşımın hızlı olmasını ve veriye erişimin kolaylaşmasını sağlar, son olarak da bu verilerden yeni ve anlamlı bilgiler elde eder. Bu süreç iş zekası kavramı olarak adlandırılmıștır.

\section{1. İş Zekası Bileşenleri (The Components of Business Intelligence)}

\subsubsection{OLTP ve OLAP sistemleri (OLTP and OLAP systems)}

İş zekası uygulamalarında kullanılan veri ambarı sistemleri temel olarak 2 aşamada incelenebilir:

OLTP (Online Transaction Processing) bilginin elektronik ortama girildiği ve anlık olarak sürekli kullanılan sistemlerdir. OLTP (Online Analytical Processing) sistemleri kullanıcılar tarafından sürekli kullanılmakta olan ERP (Enterprise Resource Planning), Kurumsal Kaynak Planlaması) sistemleri ya da Müşteri İlişkileri Yönetimi (CRMCustomer Relationship Management) sistemleri olarak düşünülebilir. OLAP sistemleri ise OLTP tarafindan oluşturulan, son kullanıcı tarafindan sürekli olarak erişilemeyen, sadece var olan verilerden anlamlı bilgiler elde edebilen sistemlerdir.

Özetle; OLTP ile OLAP sistemleri arasındaki temel farkın, OLTP'nin OLAP'a bilgi hazırlayan bir sistem olduğu söylenebilir.

OLTP ve OLAP sistemlerinin temel tasarımlarına değinmek gerekirse; OLTP sistemleri her uygulama için farklı tasarlanırken, OLAP sistemleri OLTP sistemlerinin verileri çapraz sorgulamasına izin verecek şekilde tasarlanır.

$\mathrm{Bu}$ sistemlerde temel işleyiş, günlük işlemlerde OLTP sisteminin kullanılması, daha sonra ise, bu bilgilerin analiz edilmesi ve anlamlı raporlar çıkarılması için OLAP sunucusuna aktarılmasıdır [15].

OLAP sistemlerinin bazı uygulama alanları aşağıdaki gibidir;

- Müşteri ilișkileri ve satıș

- Bankacilık

- Muhasebe

- Depo yönetimi 


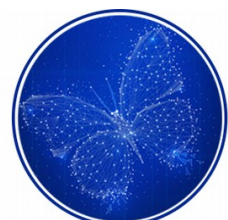

ARTIFICIAL INTELLIGENCE STUDIES

YAPAY ZEKA CALIŞMALARI

www.aistudies.org

\subsubsection{Veri madenciliği (Data mining)}

OLAP sorgularından farklı olarak elde bulunan çeşitli verilerden birtakım kontroller ve analizler yapılarak, daha önce elde bulunmayan anlamlı ve yararlı bilgilerin ortaya çıkartılması süreçlerinin bir araya gelmesi veri madenciliğini oluşturmaktadır. Ortaya çıkartılan bu bilgilerin en önemli özellikleri gerçek dünya için anlamlı olmalarıdır. Veri madenciliği ile amaçlanan, daha önceki işlemler göz önünde bulundurularak, bundan sonraki süreçlerde bu bilgilere yönelik adımların ortaya çıkartılmasıdır [16].

İş analizi, teknoloji, uygulama becerileri ve veri madenciliği tekniklerinin tamamının kullanımını içeren bir terim olarak düşünülebilir. Lee' ye göre iş analizi iş zekasının önemli bir bölümüdür ve doğrudan veri madenciliği ile desteklenir [17].

Veri Madenciliği çalışmaları amaç olarak ikiye ayrılmaktadır. Veri madenciliği yapılırken belirlenen kesin bir hedef varsa bu durum denetimli veri madenciliğidir. Kesin bir hedef yoksa ve elde edilecek sonuç için belirsizlik söz konusu ise denetimsiz ifadesi kullanılmaktadır.

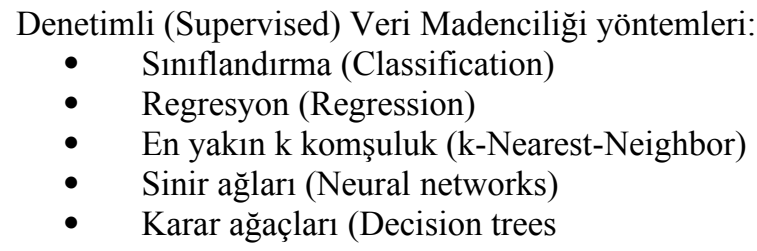

Denetimsiz (Unsupervised) Veri Madenciliği yöntemleri:

- Bağlantı Analizi (Link Analysis)

- Ardışık Zamanlı (Sequence Analysis)

- $\quad$ Aykırı Değer Analizi (Outlier Analysis)

olarak sınıflandırılabilir.

Veri madenciliğinde kullanılan yöntemlerin başlıcaları [18,19,20,21];

Regresyon analizi: Yaygın olarak kullanılan bir veri madenciliği tekniğidir. Bir ölçüt değişkeni ile bir veya daha fazla sayıda tahmin değişkenleri arasındaki ilgiyi sayısal hale dönüştürmede kullanılan istatistiksel analizdir. Regresyon analizi esas olarak değişkenler arasında ilişkinin niteliğini saptamayı amaçlar.

K-En Yakın Komşuluk: Özellikle büyük veri tabanlarında kullanılan bir sınıflandırma tekniğidir. Örnek veri noktasının bulunduğu sınıfın ve en yakın komşunun, k değerine göre belirlendiği bir sınıflandırma yöntemidir. Bu algoritma, en iyi bilinen, eski, basit ve etkili örüntü sınıflandırma yöntemlerinden biridir ve makine öğrenme algoritmaları arasında popüler olarak kullanılmaktadır.

Sinir Ağları: İnsan beyninin hesaplama mantığı baz alınarak oluşturulmuş (yapay) sinir ağları, yeni jenerasyon veri madenciliği yöntemlerindendir. Girdi ve çıktı arasında, küçük hesaplama birimlerinden elde edilen sonuçları birleştirerek sonuçlandıran bir modelleme yöntemidir.

Sınıflandırma Kuralları: Sınıflandırma kavramı, basitçe bir veri kümesi (data set) üzerinde tanımlı olan çeşitli sınıflar arasında veriyi dağıtmaktır. Sınıflandırma algoritmaları, verilen eğitim kümesinden bu dağılım şeklini öğrenirler ve daha sonra sınıfının belirli olmadığı test verileri geldiğinde doğru şekilde sınıflandırmaya çalışırlar.

Birliktelik (İlişki) Kuralları: Bu yöntemle sıklıkla bir arada ortaya çıkan ilişkilerin açığa çıkarılması sağlanmaktadır. . Bu ifade şu anlama gelmektedir: X 'in ortaya çıktığı bir durumda büyük olasılıkla Y de ortaya çıkacaktır. Hesaplama mantığı nedeniyle hızlı sonuç vermesi ve çok büyük veri setlerine kolaylıkla uygulanabilmesi Birliktelik Kuralı Analizini ticari veri tabanlarının madenciliğinde gittikçe popülerleşen bir araçtır haline getirmiştir.

\subsubsection{Sorgu ve raporlama araçları (Query and reporting tools)}

Kullanıcılara çeşitli sorgular yazma ve çalıştırma imkânı sağlayan bu sorgular ile de raporlar oluşturulabilen araçlara sorgu ve raporlama araçları denilmektedir. Oluşturulan raporlar kurum içerisinde yönetici ve karar vericilere ya da 


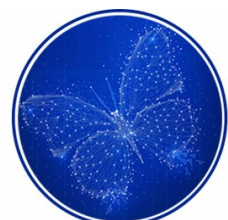

ARTIFICIAL INTELLIGENCE STUDIES

YAPAY ZEKA CALIŞMALARI

www.aistudies.org

kurum dişında müşterilere ve tedarikçilere sunulabilmektedir. Raporlar tek seferlik sunulabileceği gibi, günlük, haftalık, saatlik gibi belirlenen dönemlerde de sunulabilir. Raporu almak isteyen kullanıcılar raporu sunucuya erişerek ekranlarından ya da direk yazıcıya göndererek çıktı olarak alabilirler.

Kuruluşlar geçmişte satılan ürün ve adet değerlerini görmek isterken günümüzde gelecekte planlanan satışların gerçekleşme olasılıklarını yapay zeka uygulamaları ile görebilmektedir. $\mathrm{Bu}$ tür araçların kullanımlarının zamanla olumlu sonuçlar verdiği görüldükçe SPSS Clementine ve Business Objects gibi araçlar ortaya çıkmıştır ve gittikçe yaygınlaşmaktadır. Bu tür raporlama araçları satın alınırken kurumun önceliğine göre görsellik, performans, analiz kolaylığı, satış sonrası destek gibi konulara dikkat edilmektedir [10].

\subsubsection{ETL - veriyi çekme, dönüştürme, yükleme (Extract, transform, load)}

İş zekası araçlarının bir çok farklı veri üzerinde çalıştığı düşünüldüğünde, elde edilen verilerin sınıflandırılması gerekmektedir. Bu sınıflandırma işlemi veriler çoğaldıkça zorlaşacaktır. Bu yüzden elde edilen verilerin veri deposuna alınmadan önce süzülmesi, kurum için anlamlı verilerin alınması, anlamsız olanların da kuruma yarayacak şekilde sınıflandırılarak anlamlı hale getirilmesi, alınacak raporların ve kararların doğruluğunu etkileyecektir. ETL kavramı da bu süreçte eldeki verilerin temizlenmesi kısmına verilen isimdir. OLTP yapılarında çok sayıda kullanıcının girmiş olduğu çeşitli veriler, farklı sistemlerle ETL süreçlerinden geçirilerek veri depolarına aktarılmaktadır. ETL süreçlerinde önce harmanlanıp daha sonra anlamlı olacak şekilde temizlenmiş olan veriler, veri tabanlarında güvenli bir şekilde depolanmaktadır [11].

\section{2. İş Zekası Sistemlerinin Avantajları (The Advantages Of Business Intelligence Systems)}

İş zekâsı, işletmelerin rekabet piyasasına uyum sağlayabilmek adına piyasa hareketliliğini ve işletmenin piyasadaki yerini gösterebilmek için çevresel koşulları analiz ederken bir yandan da kurum içi iletişimi artırmak amacıyla veri analizler yapabilmeyi sağlamaktadır. İş zekası, işletmelerin tedarikten pazarlamaya kadar işletmenin tüm iş adımlarına aktif olarak katkıda bulunacaktır.

İş zekâsı uygulamalarından faydalanan birçok işletmeye bu uygulamaların sağladığı avantajlar aşağıdaki gibi siralanabilir [22,23]:

- Telefon ve e-posta trafiğinin yoğunluğunun gittikçe arttığı dönemlerde kampanya bilgilerinin analitik raporlarda kolayca iletilebilmesi,

- Ürün ve tasarım kusurlarının satışa olan etkisini minimize etmek amacıyla servis ve garanti raporlarının incelenebilmesi,

- Müşterilerin sadakat sebeplerini belirleyerek, müşteri olma potansiyeli olan alıcıların tespit edilmesi,

- $\quad$ Rakip firma müşterilerinin kendilerini tercih etmeme sebeplerinin ortaya çıkartılması,

- $\quad$ Düzenli ödeme yapan müşteriler ile tahsilat problemi yaşanan müşterilerin ayırt edilebilmesi,

- Satışı yapılan ürünlerin satış dönemleri ve buna bağlı olan tedarikçilerle yapılacak olan anlaşmalar,

- Finans kuruluşları ile yapılacak olan anlaşmalarda hangi kuruluşun tercih edileceği,

- Finans sektöründe hileli davranışların belirlenebilmesi ve caydırma yöntemlerinin incelenebilmesi olarak ifade edilebilir.

İşletmelerin müşteri tercihleri ile ilgili bilgiye sahip olmalarının gerekliliği düşünüldüğünde, elde edilen bu bilgilere dayalı olarak bulundukları pazarda talep değişikliklerine de hızlı bir şekilde adapte olmaları kaçınılmaz bir gerçektir. İşletmelerin, bu gerçeklikten yola çıkarak alıcı beklentilerini ortaya çıkarabilmek adına, eldeki bilgileri bir araya getirebilmelerinin iş zekâsı ile mümkün olabileceği söylenebilir.

Rekabet piyasasında işletmeler iç ilişkilerinin yanı sıra rakip kuruluşların da sektördeki yerlerini takip etmek zorundadırlar. Çünkü rekabetçi firmalar mevcut müşterileri elde tutarken, rakip firmaların müşterilerini de kendi müşterisi yaparak kârlılı̆̆ı artırmayı hedeflerler. Bu amaçla piyasa kuralları neyse kuruluşlar o kurala göre hareket etmek zorundadır. Böylece rekabetten kopmaksızın piyasada ayakta kalabileceklerdir. İş zekası araçları da işletmelere piyasa ve rakipler hakkında hem özet hem detaylı raporlar sunabilmektedir [10].

\section{3. İş Zekası Çözümlerinin Geleceği (The Future of Business Intelligence Solutions)}




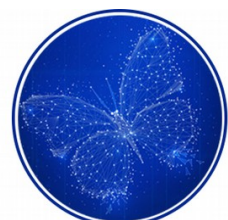

ARTIFICIAL INTELLIGENCE STUDIES

YAPAY ZEKA CALISSMALARI

Araştırmalar son yıllarda hızlı bir artış gösteren dünya çapında üretilen veri miktarının gelecek yıllarda da katlanarak artmaya devam edeceğini göstermektedir. Bu artışa paralel olarak işletmelerin iş süreçlerinde ürettiği ve depoladığı veri miktarı da artacaktır. Kurumlar hızlı bir şekilde büyüyen bu veri yığınını en uygun araçlarla yönetme ihtiyacı duymaktadırlar [24]. Bununla birlikte işletmelerin de karar vermek için kendi depoladığı verilerin dışında dışarıdan sağlayacağı verilerle analizler yapmasını gerektirecektir. IDC (International Data Corporation) tarafindan gerçekleştirilen "Dijital Dünya Araştırması" sonuçlarına göre dünyada verilerin yalnızca yüzde 0.5 ' inin analiz edildiği tahmin edilmektedir. Yakın gelecekte veriyi toplamak değil, analiz etmek daha çok önem kazanacaktır. Bu nedenle iş zekası çözümlerinin önemi daha da artacaktır. Gelecek nesil iş zekası uygulamalarında eldeki veriler üzerinden analiz ve raporlamanın ötesinde geleceğe yönelik tahminler yürütmek önem kazanacaktır [25].

\subsection{Kurumsal İş Zekası Çözümleri (Corporate Business Intelligence Solutions)}

İş Zekası çözümleri üreten çok farklı platform ve teknoloji vardır. Bunlardan en önemlileri şunlardır [26];

- IBM tarafindan sunulan IBM Cognos Express

- SAP tarafindan sunulan Business Object Edge

- $\quad$ SAS tarafindan sunulan SAS BI/ Enterprise for mid-size business

- Microsoft tarafindan sunulan Performance Point Server/ Excel/ SQL Server/ Microsoft Strategy Reporting Suite

- Oracle tarafindan sunulan Oracle Business Intellegence Suite

- QlikView tarafindan sunulan QlikView

\section{5. İş Zekası çözümleri için başarı faktörleri (Key success factors of Business Intelligence)}

Garcia ve Pinzon tarafından yapılan bir çalışmaya göre günümüzde iş zekası entegrasyonları teknolojik ve yönetimsel nednelerden dolayı \%70 \%80 oranlarında başarısız olmaktadır [30]. Bu çalışmada uzaman kişilerle yapılan görüşmeler sunucu bir iş zekası entegrasyonu için başarıyı etkileyen faktörler belirlenmiştir. Uzmanlar ile yapılan görüşmeler kayıt altına alınmıştır. Bu görüşme kayıtları analiz edilerek iş zekası entegrasyonu başarısını etkileyen faktörler ve bu faktörlerin ağırlıkları belirlenmiştir. Şekil 4’te bu faktörler görülebilmektedir. Diğer çalışmalarda da benzer şekilde İş zekası entagrasyonu için başarı faktörleri olarak personel kalitesi, teknoloji, eğitim, çevresel etkiler ve proje planı gibi etkenler belirtilmiştir [31-33].

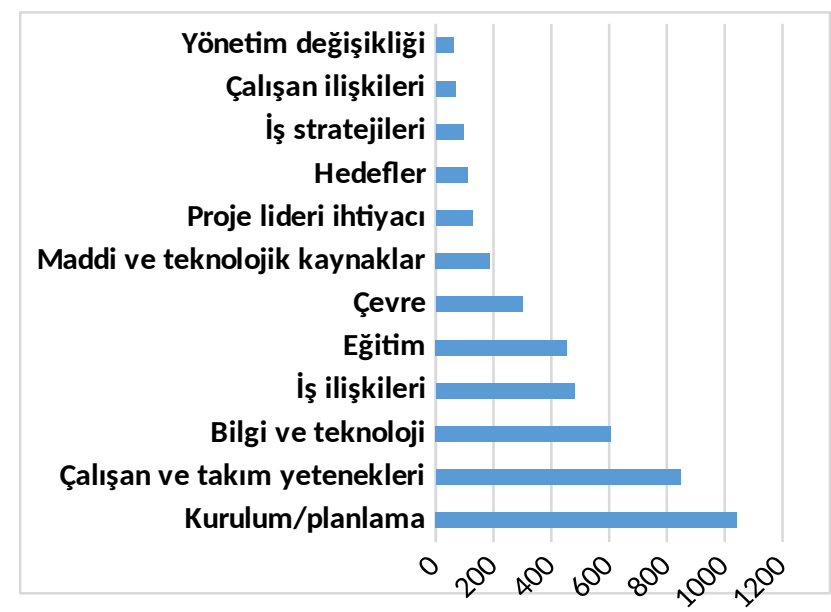

Şekil 4. İ̧̧ Zekası çözümleri için başarı faktörleri [30] (Key success factors of Business Intelligence)

\section{BENZER ÇALIŞMALAR (SIMILAR STUDIES)}

Miskuf ve Zolotova iş zekası çözümlerinin üretim verileri üzerinde uygulanmasına ilişkin bir çalışma yapmışlardır [35]. İş zekası çözümleri öncelikle iş verileri (business data) için kullanılmaktadır. Wonderware ve Rockwell gibi firmalar üretim verileri (manufactoring data) üzerine çözümler sunmaktadır. Bu tür çözümler ise üretim zekası olarak adlandırılmıştır. Araştırmacılar Slovakya' nın en büyük özel kurumu olan U.S. Steel' in verilerini çok boyutlu analizlere 
ARTIFICIAL INTELLIGENCE STUDIES

YAPAY ZEKA CCALISMALARI

www.aistudies.org

uygun hale getirmiş ve IBM ve Oracle iş zekası çözümlerini uygulamıştır. Uygulama sonucunda U.S. Steel firmasının zaten halihazırda kullanmakta olduğu Cognos sisteminin üretim verileri üzerinde de kullanılabildiği yöneticilere üretime ilişkin raporlar sunabildiği görülmüştür. Sonuç olarak neredeyse her büyük firma tarafından kullanılan iş zekası çözümlerinin ek bir maliyet gerektirmeden üretim verileri üzerine de uygulanabileceği ifade edilmiştir.

Khan vd. eğitim sistemlerinde iş zekası çözümleri için veri madenciliği tekniklerinin uygulanması ilişkin bir çalışma yapmıştır [36]. Çalışma kapsamında öğrencilere ait akademik başarı notları veri madenciliği tekniklerine uygun hale getirilmiş ve Apriori algoritması kullanılarak öğrencilerin akademik faaliyetlerini izleme ve yönlendirmede faydalı olacak bilgilere erişilmiştir. Örnek çalışma sonuçlarına göre İngilizce dersinden başarısız olan öğrencilerin diğer çoğu dersten de başarısız olduğu ayrıca İngilizce ve matematik dersinden başarısız olan öğrencilerin programlama derslerinde de başarısız olduğu bilgilerine erişilmiştir. Okul yönetimi alanında iş zekası uygulamasına yönelik başka bir çalışma da Hudek vd. tarafından yapılmıştır [37]. Bu çalışmada araştırmacılar tarafından yerel yönetim bazında ilgili okulların verileri kullanılarak finans, zaman yönetimi ve okul dışı faaliyetler de dikkate alınmış ve yerel yönetimin yöneticilerine stratejik kararlar alınması aşamalarında destek sağlanmıştır.

Wang, bütçe sistemi için iş zekası çözümü tasarımı ve uygulanmasına ilişkin bir çalışma yapmıştır [38]. Sunulan çözüm için Microsoft SQL Server veritabanı ve ODBC (Open Database Connectivity) araçları kullanılmıştır. Sunulan çözüm sayesinde kapsamlı bütçe analizleri, bütçe yürütme ve ayırma işlemleri yapılabilmiş ve yöneticiler için zamanında ve hızlı karar vermelerine imkân sağlanmıştır.

Keerin tarafından yapılan bir çalışmada personel yönetimi için iş zekası çözümü geliştirmiştir [39]. Bu sistem için veritabanı olarak Mysql, web ortamında sunum yapmak için PHP teknolojilerinden faydalanılmıştır. Sunulan çözüm genel olarak verilerin ayıklanması, yönetilmesi ve analiz edilmesi sayesinde karar verme aşamalarında yardımcı bilgiler sağlamaktadır. Sunulan sistem hakkında anket ile memnuniyet düzeyi ölçülmüş ve kullanıcıların genellikle çok memnun oldukları belirlenmiştir.

\section{PERAKENDE SEKTÖRÜNDE KAMPANYA YÖNETIMINE YÖNELIK İŞ ZEKASI UYGULAMASI (BUSINESS INTELLIGENCE APPLICATION FOR CAMPAIGN MAGAGEMENT IN THE RETAIL SECTOR)}

Perakende satış gerçekleştiren gıda sektörüne yönelik marketlerde tüm satışlar barkod sistemleri üzerinden yapılmaktadır. Kasalardan yapılan satışlar belli periyodlarda günlük, haftalık ya da aylık olarak veri tabanına aktarılmaktadır. Veri tabanına aktarılan bu veriler analiz edilerek, müşterilerin alışveriş alışkanlıkları tespit edilebilmektedir. Bu çalışma kapsamında; bu tespitlerin nasıl yapılacağı ve yapılan çalışmaların kurumların satışlarına ne gibi yansımaları olacağı tespit edilmeye çalışılmıştır. Bu amaçla çalışmanın yöntemini aşağıdaki şekilde açıklamak mümkündür:

- $\quad$ Öncelikle Oracle Database sunucusu üzerinde örnek tablolar ve veriler oluşturulmuştur.

- Oluşturulan satış verilerinde, analizler yapılarak hızlı satılabilen ve yüksek kârla satılabilen ürünler tespit edilmiştir.

- $\quad \mathrm{Bu}$ verilerden müşterilerin alışveriş alışkanlıkları tespit edilerek müşterilerin alışveriş alışkanlıklarına göre yapılacak olan promosyonların, müşterileri hedef ürünleri birlikte almaya teşvik edilmesi sağlanmaya çalışılmıştır.

- Müşterilerin alışveriş alışkanlıklarının tespit edilmesi için birliktelik kuralları kullanılmıştır.

Makale kapsamında, pazar sepet analizi konusuna yoğunlaşarak, apriori algoritması ile hangi ürünlerin birlikte satıldığı tespit edilmiştir. Birlikte satılan ürünler tespit edildikten sonra Microsoft firması tarafından 2013 yılında ortaya çıkartılan ve sürekli geliştirilen PowerBI uygulaması ile raporlar oluşturulmuştur.

\subsection{Apriori Algoritması (Apriori Algorithm)}

Birliktelik kuralları, belli veriler arasındaki öngörülmeyen ilişkileri ortaya çıkarmaktadır. Birliktelik kuralları, veri madenciliğinin en önemli unsurlarından biridir. Birliktelik kuralları kavramı ilk olarak 1993 yılında Agrawal, Imielinski ve Swami tarafından ortaya atılmıştır. Birliktelik kuralları yaygın olarak pazar sepeti analizi, promosyon analizleri, katalog ve yerleşim düzeni tasarımlarında kullanılmaktadır [27].

Apriori algoritması ilk olarak 1994 yılında Agrawal ve Srikant tarafından geliştirilen bir algoritmadır. Apriori algoritmasında bilgiler her zaman bir önceki işlemin çıtıtlarından elde edildiği için, "prior” yani “önceki” kelimesinden esinlenilerek Apriori ismi verilmiştir. Birliktelik, çıkarım algoritmaları içerisinde en çok kullanılan algoritmadır. 


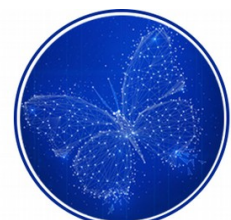

\section{ARTIFICIAL INTELLIGENCE STUDIES \\ YAPAY ZEKA CALISSMALARI \\ 2018, 4(1): 8-25}

www.aistudies.org

Apriori algoritmasında temel kural, "sık tekrar eden nesne kümesinin alt kümeleri de sık tekrar etmelidir" şeklindedir. Algoritmanın çalışma mantığına göre, ilk olarak sık tekrar edilen küme bulunmakta ve bu kümeye bir isim verilmektedir. Bulunan bu küme sık tekrar eden 2 elemanlı kümenin elde edilmesinde kullanılacaktır. Algoritmaya göre bu süreç sürekli tekrar ederek, sık tekrar eden kümeleri bulacaktır. Sık tekrar eden öğelerin tespit edilebilmesi için veri tabanındaki tüm verilen taranması gerekmektedir [28].

Minimum destek değerlerinin ve s1k ürün kümelerinin, minimum güven parametresinin \%50 olduğu bir örnek ile algoritma açıklanacak olursa;

4 farklı alışverişte Tablo 1'deki ürünler birlikte alınmıştır.

Tablo 1. Satış fişleri (Sales slip)

\begin{tabular}{|c|l|}
\hline Fiş No & Fișteki Ürünler \\
\hline 1 & Domates, Salatalı, Zeytin, Ekmek Peynir \\
\hline 2 & Domates, Zeytin, Yoğurt \\
\hline 3 & Domates, Ekmek, Peynir, Yoğurt \\
\hline 4 & Salatalık, Salam, Sucuk \\
\hline
\end{tabular}

1 öğeli kümelerin destek değerleri Tablo 2’ de verilmiştir.

Tablo 2. Bir öğeli kümelerin destek değerleri (Support value of oneelement clusters)

\begin{tabular}{|c|c|}
\hline Ürünler & Destek Değerleri \\
\hline Domates & $\% 75$ \\
\hline Salatalık & $\% 50$ \\
\hline Zeytin & $\% 50$ \\
\hline Ekmek & $\% 50$ \\
\hline Yoğurt & $\% 50$ \\
\hline Peynir & $\% 50$ \\
\hline Salam & $\% 50$ \\
\hline Sucuk & $\% 25$ \\
\hline
\end{tabular}

Tablo 3. Minimum destek değeri \%50'den büyük olanlar (Products the minimum support value of which are $50 \%$ greater)

\begin{tabular}{|c|c|}
\hline Ürünler & Destek Değerleri \\
\hline Domates & $\% 75$ \\
\hline Salatallk & $\% 50$ \\
\hline Zeytin & $\% 50$ \\
\hline Ekmek & $\% 50$ \\
\hline Yoğurt & $\% 50$ \\
\hline
\end{tabular}

2 öğeli kümelerin destek değerleri Tablo 4'de listelenmektedir.

Tablo 4. İki öğeli kümelerin değerleri (Support values of two element clusters)

\begin{tabular}{|c|c|}
\hline Ürünler & Destek Değerleri \\
\hline Domates, Salatalı & $\% 25$ \\
\hline Domates, Peynir & $\% 50$ \\
\hline Domates, Zeytin & $\% 50$ \\
\hline Domates, Ekmek & $\% 50$ \\
\hline Domates, Yoğurt & $\% 50$ \\
\hline Salatallk, Zeytin & $\% 25$ \\
\hline Salatallk, Peynir & $\% 25$ \\
\hline Salatalı, Ekmek & $\% 25$ \\
\hline Salatallk, Sucuk & $\% 25$ \\
\hline Salatallk, Salam & $\% 25$ \\
\hline Zeytin, Ekmek & $\% 25$ \\
\hline Zeytin, Peynir & $\% 25$ \\
\hline Zeytin, Yoğurt & $\% 25$ \\
\hline Ekmek, Peynir & $\% 50$ \\
\hline Ekmek, Yoğurt & $\% 25$ \\
\hline
\end{tabular}




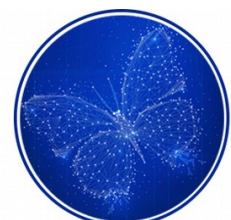

ARTIFICIAL INTELLIGENCE STUDIES

YAPAY ZEKA CALISSMALARI

Tablo 5. Minimum destek değeri \%50'den büyük olanlar (Products the minimum support value of which aregreater than 50\%)

\begin{tabular}{|c|c|}
\hline Ürünler & Destek Değerleri \\
\hline Domates, Peynir & $\% 50$ \\
\hline Domates, Zeytin & $\% 50$ \\
\hline Domates, Ekmek & $\% 50$ \\
\hline Domates, Yoğurt & $\% 50$ \\
\hline Ekmek, Peynir & $\% 50$ \\
\hline
\end{tabular}

Tablo 6. Üç öğeli kümelerin destek değerleri (Support value of three element clusters)

\begin{tabular}{|c|c|}
\hline Ürünler & Destek Değerleri \\
\hline Domates, Peynir, Zeytin & $\% 25$ \\
\hline Domates, Peynir, Ekmek & $\% 50$ \\
\hline Domates, Peynir, Yoğurt & $\% 25$ \\
\hline Domates, Zeytin, Ekmek & $\% 25$ \\
\hline Domates, Zeytin, Yoğurt & $\% 25$ \\
\hline Domates, Ekmek, Yoğurt & $\% 25$ \\
\hline Ekmek, Peynir, Yoğurt & $\% 25$ \\
\hline Ekmek, Peynir, Zeytin & $\% 25$ \\
\hline
\end{tabular}

Tablo 7. Minimum destek değeri \%50'den büyük olanlar (Products the minimum support value of which are greater than $50 \%$ )

\begin{tabular}{|l|l|}
\hline Ürünler & Destek Değerleri \\
\hline Domates, Peynir, Ekmek & $\% 50$ \\
\hline
\end{tabular}

Verilen destek şartını sağlayan ürün kümeleri bulunduktan sonra birliktelik kuralları devreye alınabilmektedir. Minimum destek değeri 50 olarak belirlenmiştir. Destek değeri \%50'den büyük olan kümelerin tespit edilmesi, örneği anlaşılır hale getirmektedir. Bu bilgilere göre kümeyi oluşturan ürünlerin destek değerleri \%50'ye eşit ya da \%50'den büyük olmalıdır.

Tablo 8. Birlikte satılan ürünler (Products that are sold together)

\begin{tabular}{|l|l|}
\hline$\ddot{\text { Ürünler }}$ & Güven Değerleri \\
\hline Domates, Peynir > Ekmek & $\% 100$ \\
\hline
\end{tabular}

Tablo 8'de ortaya çıkan sonuca göre Domates, Peynir ve Ekmek ürünlerinden ikisini alan müşteriler üçüncü ürünü de kesinlikle almaktadır. Bu bilgilere istinaden stok takibi yapılacak ve kampanyalar düzenlenecektir.

\subsection{Power BI Uygulaması (Power BI Applications)}

Power BI uygulaması, Microsoft firması tarafından 2013 yılında geliştirilmiştir. Power BI teknik olmayan kurum kullanıcıları için geliştirilmiş olan ve bulut tabanlı bir iş çözümleme hizmetidir. Power BI kullanılarak, operasyonel panolar aracılığıyla kurumların anlık durumları incelenebilmekte ve görsel raporları ile kurum verileri derinlemesine araştırılabilmektedir.

Power BI mimarisi farklı ortamlardan verilerin okunarak ve analiz edilerek görsel grafikler oluşturulmasına olanak sağlamaktadır. Power BI Desktop uygulaması ile geliştirilen raporlara powerBI.com sayfası ile web ortamından ve iOS veya Android tabanlı mobil cihazlardan ulaşılabilmektedir. 


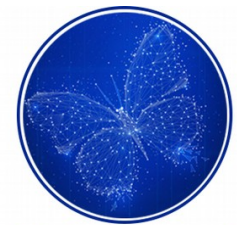

artificial intelligence studies
ARTIFICIAL INTELLIGENCE STUDIES

YAPAY ZEKA CCALISSMALARI

2018, 4(1): 8-25

www.aistudies.org

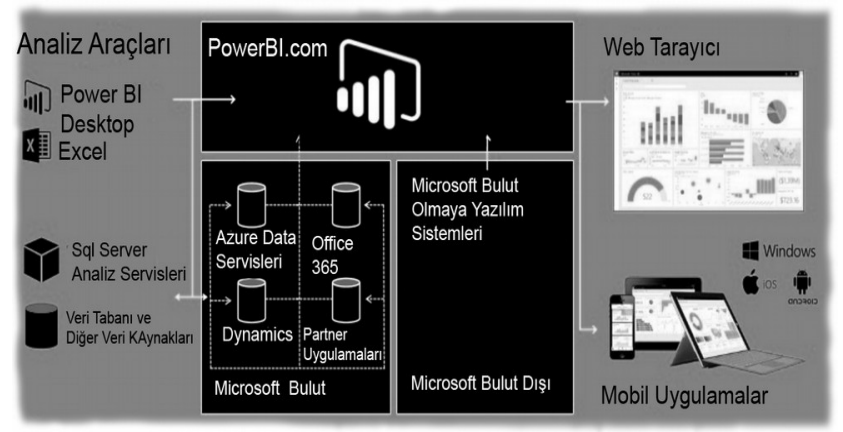

Şekil 5. Power BI Mimarisi (Power BI Architecture)

Power BI ile birçok ortamdan kolayca alınan veriler, henüz verilerin okunması aşamasında ilişkilendirildiği için raporların oluşturulması sırasında kullanıcıya kolaylık sağlamaktadır.

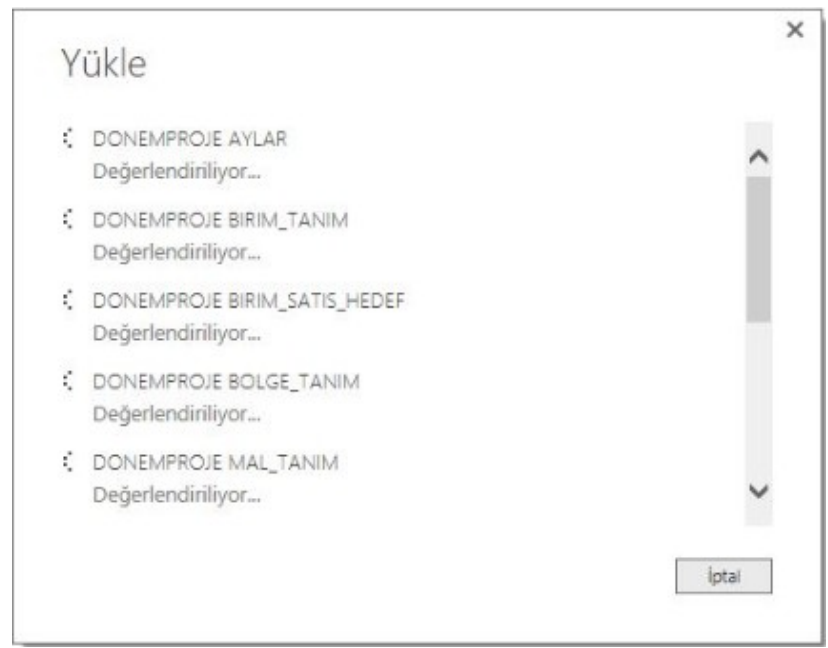

Şekil 6. Verilerin analiz edilmesi (Analysis of data)

Verilerin ve tablo yapılarının analiz edilerek PowerBI içerisine yüklenmesinden sonra kullanıcılar tablolar arasındaki tüm ilişkileri görebilmektedir. Gereksiz olanlar tamamen kaldırılarak, yeni ilişkiler eklenebilmekte ya da anlık olarak kapatabilmektedir.

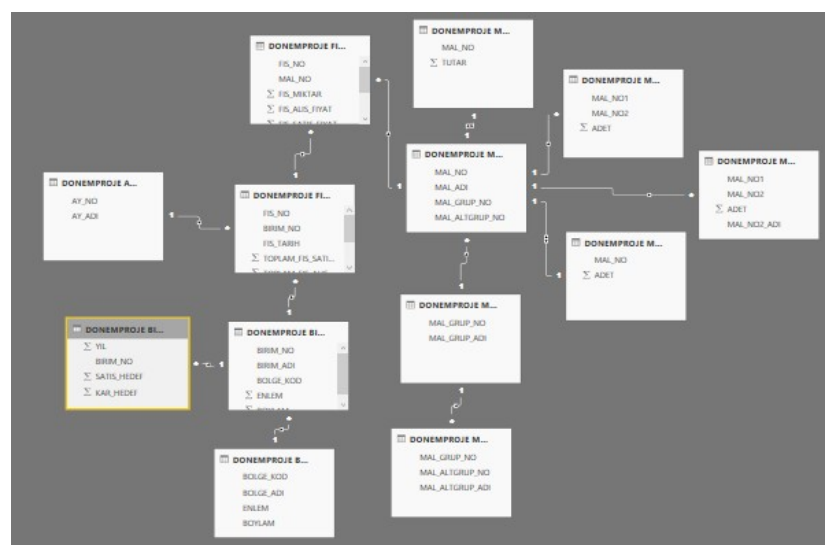

Şekil 7. Tablo ilişkileri (Table relationships)

İlişkilerin istenilen koşullarda yapılandırılmasından sonra raporların oluşturulabileceği, şık görünümlü ve kullanımın basit olacağı ilk bakışta anlaşılabilen PowerBI boş rapor ekranı açılmaktadır. Sağ tarafta uygulama içerisine alınan 


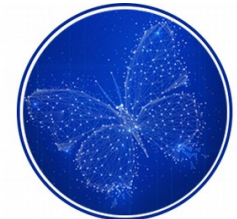

\section{ARTIFICIAL INTELLIGENCE STUDIES \\ YAPAY ZEKA CALISSMALARI \\ 2018, 4(1): 8-25}

tablolar ve rapora eklenebilecek grafiklerin olduğu listeler bulunmaktadır. PowerBI ile yeni bir rapor oluşturmak için kullanıcıların altyapıya ihtiyacı bulunmamaktadır. Sağ tarafta listelenmiş olan grafiklere kullanıcının bir kez tıklaması yeterli olmaktadır. Raporun çalışma sistemine ve listeleyebileceği değerlere göre tanımların yapılacağı alanlar ekranın sağ tarafında listelenmiştir.

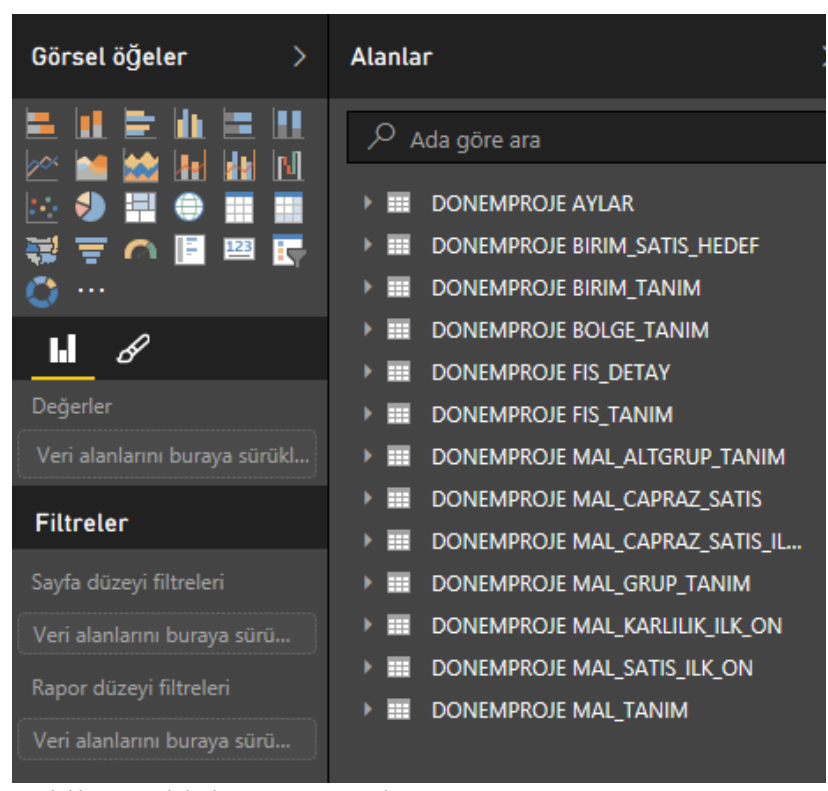

Şekil 8. Tablolar ve Raporlar (Tables and reports)

\subsection{1. Ürün bazında raporlar (Reports on the basis of Some Products)}

Uygulama içerisine yüklenen satış verilerine istinaden hangi ürünlerde daha çok stok hareketi olduğunun tespit edilebilmesi için örnek bir rapor oluşturulmuştur. Bu rapor ile amaç, daha fazla hareketi olan stoklar için depoda daha fazla yer açılarak, bu ürünlerde temin sorunları olması durumunda satışın sürekliliğini sağlamaktır. Mağaza içerisinde ilk aradığı ürünü bulamayan müşteri, diğer alacaklarına bakmadan rakip firmaları tercih edebilmektedir. Böyle bir süreçte sadece stokta olmayan ürün değil, müşterinin ilgili ürün ile birlikte alacağı diğer ürünlerin de satışı durmuş olmaktadir.

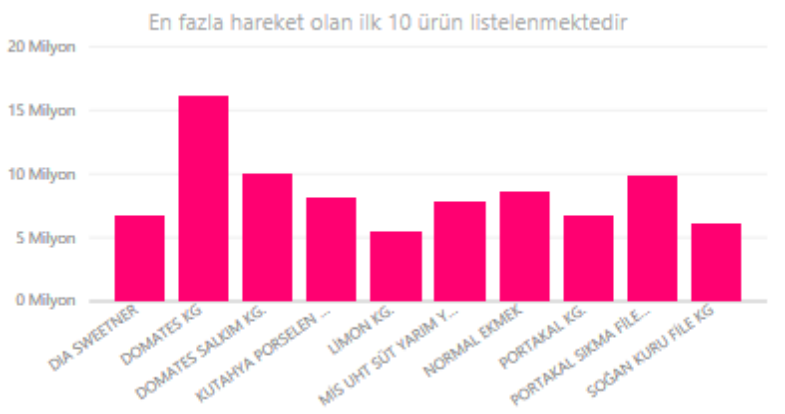

Şekil 9. En fazla satılan ürünler listesi (Top selling products lists)

En fazla satılan ürünler ile birlikte mağaza deposunda diğer ürünlere oranla daha fazla yer ayrılması gereken bir diğer ürün grubu da en kârlı satılan ürünlerdir. Yüksek kar ile satılan ürünler, düşük kar ile satılan ya da herhangi bir nedenden dolayı zararına satılan ürünlerin açıklarını kapatabilmektedir. Bu sebeple yüksek kar ile satılan ilk 10 ürünün listelendiği bir rapor karar vericilere yol gösterici olmaktadır. 


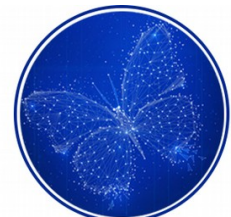

ARTIFICIAL INTELLIGENCE STUDIES

YAPAY ZEKA CALISSMALARI

2018, 4(1): 8-25

artificial intelligence studies

www.aistudies.org

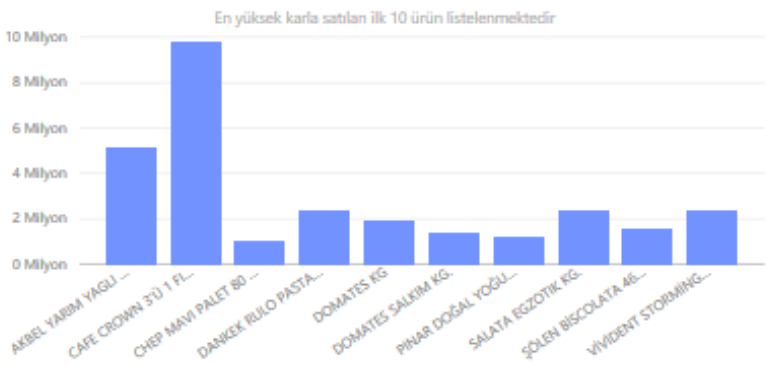

Şekil 10. En kârlı ürünler listesi (Most profitable products lists)

Apriori algoritması kullanılarak geliştirilen bir uygulama ile yeni bir tabloda birlikte satılan ürünler ve bu ürünlerin kaç kez birlikte satıldıkları tespit edilmiştir. En fazla hareket olan ve en yüksek kârla satılan ürünlerle birlikte satılan ürünler, yeni başlatılacak olan promosyonlarda dikkate alınırsa promosyon sürecindeki hareketliliği arttırabilir. Kahve ürünü ile birlikte en fazla satılan çikolata ürününün, kahve ürünüyle aynı rafla bulunması müşterinin kahve alırken çikolata ürününü de hatırlamasında yardımcı olabilir. Bu amaçla en çok satılan ve en yüksek kârla satılan ürünlerin birlikte satıldığg ürünleri gösteren bir rapor hazırlanmıștır. Şekil 11'e bakıldığında, en çok satılan ürünlerden birisi olan domates ile birlikte satılmış olan ürünlerin pasta grafiğinde satış oranlarına göre pay aldıkları görülmektedir. Rapor bize domates ürününün bulunduğu alışveriş sepetlerinde ikinci ürün olarak en fazla satılan ürünün salatalık olduğunu göstermektedir.

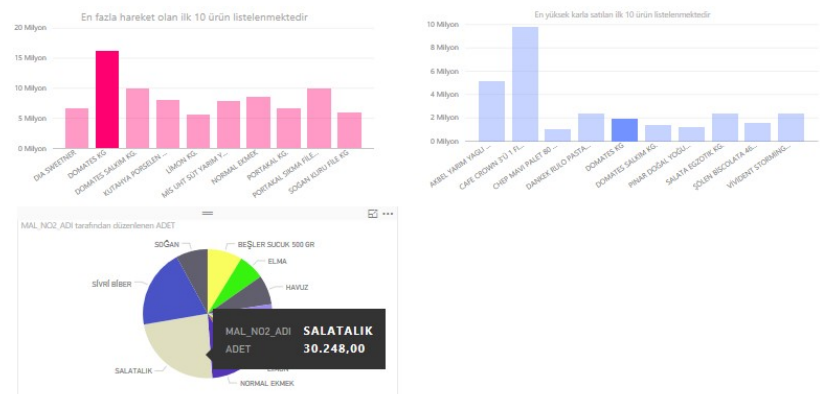

Şekil 11. Birlikte satılan ürünler (Products that are sold together)

En fazla satılan, yüksek kârla satılan ya da birlikte satılan ürünler ile ilgili bir kampanya oluşturulacaksa, bu ürünlerin hangi dönemlerde daha fazla satıldıkları ve hangi dönemlerde birlikte satıldıkları önem arz etmektedir. Baklava ürünü ile birlikte dondurma ürünü çok fazla satılmasına rağmen iki ürünü kapsayan kampanyaların kış aylarında başarıya ulaşmasının pek mümkün olmayacağı bir gerçektir. Kampanya döneminin doğru şekilde tespit edilebilmesi için, ürünlerin hangi dönemlerde daha fazla satışa ulaştıklarını doğru analiz etmek gerekmektedir. Bu amaçla ürünlerin tespit edildikleri sayfa içerisinde dönemlere göre satış oranlarının görünmesi gerekmektedir. Şekil 12'ye bakıldığında Domates ürününün Ocak ayında diğer aylara göre çok daha yüksek oranda satıldığı anlaşılmaktadır.

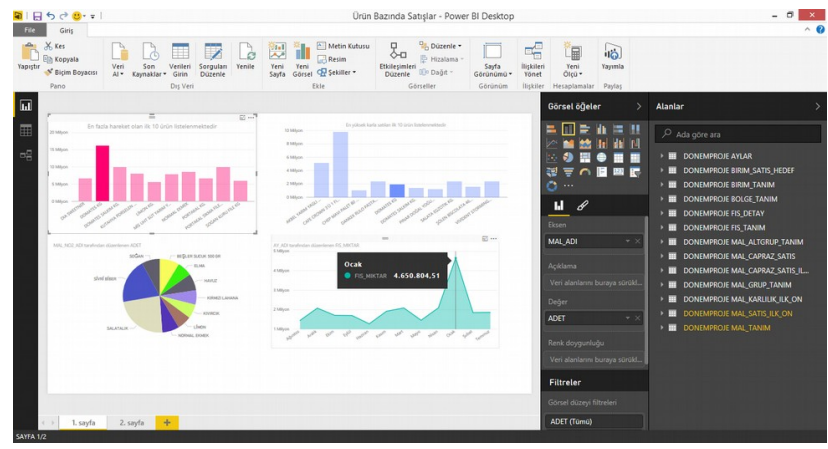

Şekil 12. Satış dönemleri (Sales periods) 


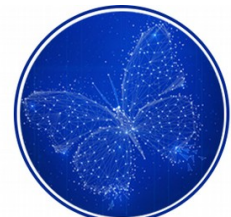

\section{ARTIFICIAL INTELLIGENCE STUDIES \\ YAPAY ZEKA CALIŞMALAR \\ 2018, 4(1): 8-25}

Karar alıcıları doğru analizler ve tespitler yapılması konusunda yönlendirecek olan ürün bazındaki rapor, istenilen bilgileri verebilecek tasarıma geldiğinde Power BI üst menüsünde bulunan Yayımla butonu ile PowerBI sayfasında yayınlanmaktadır. Bu özellik ile raporlara herhangi bir lokasyondan erişilebilmektedir. Şekil 13'te raporun web ortamında yayınlamış hali görünmektedir.

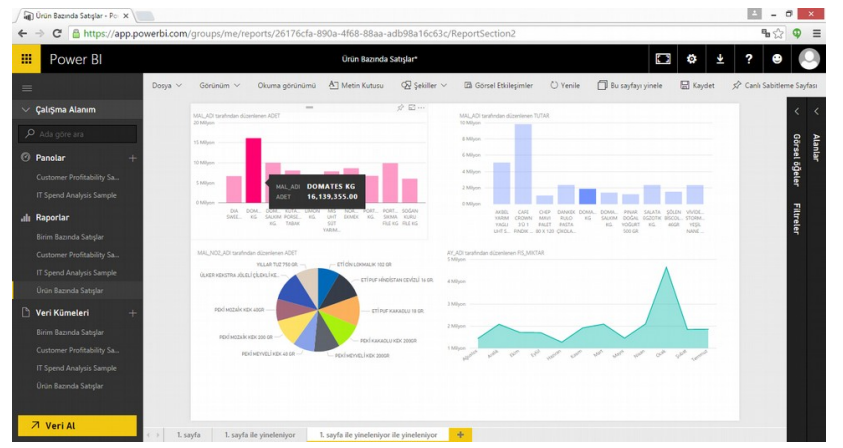

Şekil 13. Web ortamına uygulanması (Web applications)

\subsubsection{Birim bazında raporlar (Reports on some sections)}

Kâr amaçlı kurulan her kurum belli bir gelir düzeyine ulaşmak amacıyla çalışmaktadır. Yapılan ve yapılacak olan yatırımlar sonucunda kurumların hedefledikleri kârlılık düzeyine ulaşmak ilk ve en önemli hedeftir. Birden fazla mağazası olan kurumların, hem genel hedefleri hem de birimler bazında hedefleri olmaktadır. Bu amaçla birimlerin satış tutarlarının tespit edilebilmesi amacıyla birim bazında raporlar yapılmıştır. Power BI uygulamasının harita özelliği ile birimlerin harita üzerinde konumları tespit edilerek, hangi bölgelerdeki müşterilere hitap edilemediği tespit edilmiştir. Power BI harita raporu ile enlem ve boylam değerleri bildirilerek, hangi lokasyonlarda ne kadar satış rakamına ulaşıldığı görülmüştür. Enlem ve boylam değerleri verildiğinde, harita üzerindeki yerleşim Power BI tarafından yapılmaktadır. Şekil 13’te Bölge Müdürlükleri bazında satış rakamları görülebilmektedir.

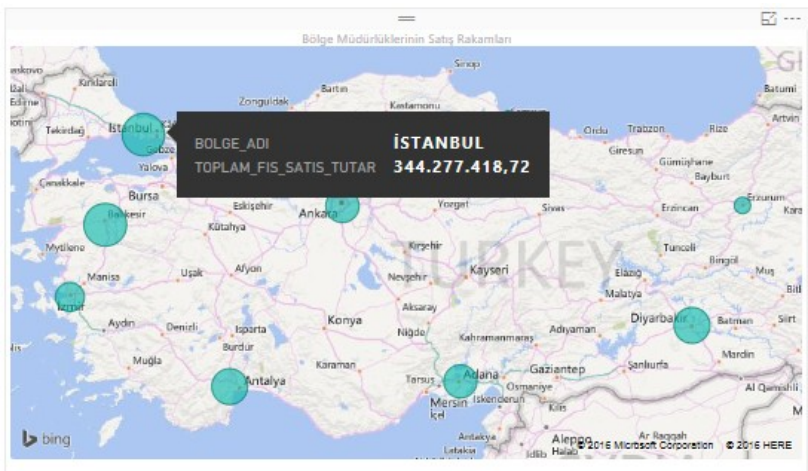

Şekil 14. Bölge satış rakamları (Regional sales figures)

Bölge Müdürlükleri'ne ait rakamlar kurumun genel durumu hakkında bilgi vermiş olmasına rağmen, beklenti ile mevcut durum arasındaki farkı vermemektedir. Bölge Müdürlükleri’nin rakamları birden fazla mağazanın toplamını vermektedir. $\mathrm{Bu}$ şekilde yapılan yorumlar beklentiyi karşılamayan ve beklentinin üzerinde bir başarı elde birimi göstermemektedir. Birimler bazında hedeflerin ve mevcut durumun doğru analiz edilebilmesi için rapora yeni bir görsel eklenmiştir. Yeni görsel, bölgesel harita ile ilişkili çalışmakta ve hangi bölge seçilirse, o bölgenin mağazalarının satış ve hedef rakamlarını göstermektedir. Bu şekilde hangi mağazanın beklentiyi karşılamadığı, hangi mağazaların hedefin üzerine çıktığı tespit edilmiştir. Satış rakamları ile hedeflerin karşılaştırılması sonucunda ortaya çıkan sonuca göre, belli mağazaların başarısızlık sebepleri ile yüksek başarı elde eden mağazaların çalışma prensipleri incelenmiştir. Şekil 15'te yayınlanan rapora göre İstanbul Bölge Müdürlüğü’ne bağlı olan 10 mağaza içerisinde sadece bir tanesi hedefe ulaşabilmiştir. Bu bilgiye göre, gelecek dönemlerde hedef rakamları azaltılabilir ya da kampanya/reklam gibi satış arttırıcı unsurlara ağırlık verilmesi gerektiği söylenebilir. 


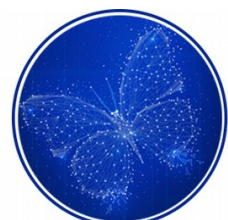

artificial intelligence studies

ARTIFICIAL INTELLIGENCE STUDIES

YAPAY ZEKA CALISMMLARI

2018, 4(1): 8-25

www.aistudies.org

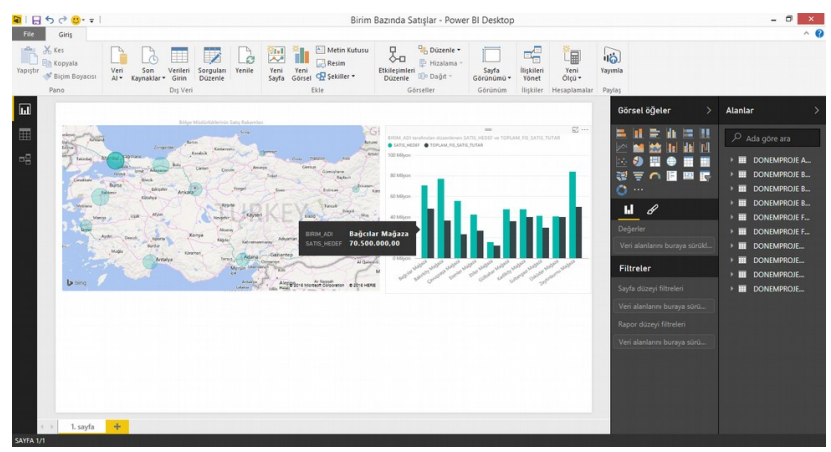

Şekil 15. Mağaza satış rakamları (Section sales figures)

Şekil 15'te mağazalar bazında satış ve hedef rakamlarındaki farklılık görünse de, hedefe ulaşmak için gereken satış rakamları net olarak anlaşılamamaktadır. Şekil 16'da rapora hız bar eklenerek, seçilen birimde satışların hedefe ulaşma oranları ilk bakışta anlaşılabilmektedir.

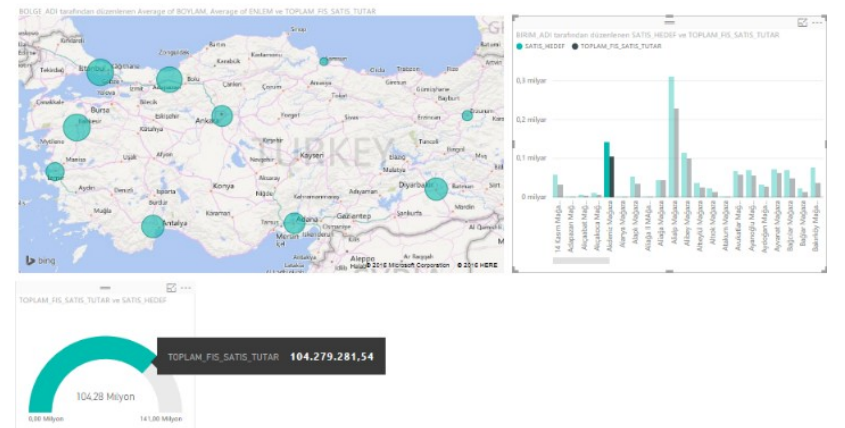

Şekil 16. Satış - Hedef oranları (Sales - Target rates)

\section{SONUÇ VE DEĞERLENDIRME (RESULT AND EVALUATION)}

Bilişim teknolojileri, rekabetin arttığı iş koşullarında kuruluşların müşteri eğilimlerine ulaşmalarına olanak sağlamaktadır. Kuruluşlar, müşterileri eğilimlerini doğru tespit edebildikleri ölçüde ayakta kalabilmektedir. Müşteriye yönelik sunumların müşteriyi memnun etme oranı, müşterinin alışkanlıklarını ve beklentilerini tespit etmeyle doğru orantılıdır. Müşterilerin alışveriş alışkanlıklarının tespit edilebilmesi için kuruluşların satış bilgilerini kayıt altında tutmaları ve bu bilgileri sürekli olarak güncellemeleri gerekmektedir.

Makale kapsamında iş zekasının önemli bileşenleri olarak veri madenciliği ve karar destek sistemleri hakkında bilgi verilmiştir. Bu aşamada veri ambarı oluşturma aşamalarından verilerin modellenmesi, kaydedilmesi, düzenlenmesi ve analiz edilmesi konularında bilgi verilmiştir.

Uygulama kapsamında Oracle veri tabanı üzerinde oluşturulan örnek veriler oluşturulmuş, birliktelik kuralları ile müşterilerin alışveriş alışkanlıkları belirlenmiş ve Power BI uygulaması ile de görsel raporlarlar sunulmuştur. Power BI uygulamasının basit kullanım arayüzü sayesinde teknik olmayan kullanıcılar istedikleri ilişkiler doğrultusunda görsel tablolara ulaşabilmektedir. Örnek satış verileri kullanılarak en kârlı ürünler, en fazla satılan ürünler, birlikte en fazla satılan ürünler, satış dönemleri ve mağaza satış bilgilerine ilişkin görsel raporlara yer verilmiştir. Yapılan çalışma sonucunda işletmelere pazardaki yeri ve mevcut durumlarını hızlı bir şekilde görebilme imkânı sunulmuştur. Müşteri alışkanlıklarının tespit edilmesi amacıyla geçmiş dönemlerdeki satışlar incelenmiştir. Gelecekte satışları arttırmak için alınabilecek önlemler konusunda kuruluşların geçmiş dönemlerden nasıl yararlanabilecekleri vurgulanmıştır.

Gelecekte bu alanda yapılacak çalışmalar için, son dönemlerde çok popüler hale gelen büyük veri ve bulut bilişim kavramlardan faydalanılması sunulacak iş zekası çözümünün daha verimli olmasını sağlayacaktır. 


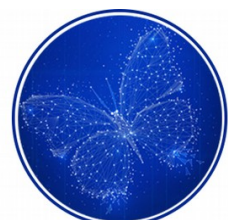

\section{ARTIFICIAL INTELLIGENCE STUDIES \\ YAPAY ZEKA CCALISYMALARI}

2018, 4(1): 8-25

artificial intelligence studies

www.aistudies.org

\section{KAYNAKLAR (REFERENCES)}

X[1] Ç. Taşkın, G. Emel, "Veri Madenciliğinde Kümeleme Yaklaşımları Ve Kohonen Ağları İle Perakendecilik Sektöründe Bir Uygulama", Süleyman Demirel Üniversitesi İktisadi Ve İdari Bilimler Fakültesi Dergisi, 15, 3, pp. 395-409, 2010.

[2] İ. Savaşçı, "Tüketicinin Perakendeci Marka Tercihleri: İzmir Hipermarketleri Kapsamında Bir Arastırma", Ege Üniversitesi Sosyal Bilimler Enstitüsü İşletme Anabilim Dalı, 2002.

[3] Ö. Akgöbek, F. Çakır, "Veri Madenciliğinde Bir Uzman Sistem Tasarımı", XI. Akademik Bilişim Konferansı Bildirileri, Harran Üniversitesi, Şanlıurfa, 11-13 Şubat, 2009.

[4] M. Tekin, M. Zerenler, A. Bilge, "Bilişim Teknolojileri Kullanımının İşletme Performansına Etkileri: Lojistik Sektöründe Bir Uygulama", İstanbul Ticaret Üniversitesi Fen Bilimleri Dergisi, 4(8), pp. 115-129, 2005.

[5] M. Ayanoğlu, K. Mert, E. Giray, "Perakende Sektöründe Veri Madenciliği Vageçilmez mi? Alternatifi CRM Mi?", Yöneylem Araştırmasl/Endüstri Mühendisliği XXIV Ulusal Kongresi, Gaziantep - Adana, 15-18 Haziran, 2004.

[6] B. D. Akça, A. Doğan, U. Özcan, "Analitik Hiyerarşi Süreci Kullanılarak Kişi Takip Cihazı Seçimi", International Journal Of Informatics Technologies, 8, 1, 2015.

[7] S. Öztürk, "Bir Üretim İşletmesinde Bireysel Performans Değerleme Sistemi Kurulumu ve Bir Karar Destek Sistemi Tasarımı", Yüksek Lisans Tezi, Başkent Üniversitesi, Fen Bilimleri Enstitüsü, 2008.

[8] Ö. Turunç, "Bilgi Teknolojileri Kullanımının İşletmelerin Örgütsel Performansına Etkisi", Doktora Tezi, Süleyman Demirel Üniversitesi, Sosyal Bilimler Enstitüsü, 2006

[9] S. Çebi, "Aksiyomlarla Tasarım Esaslı Bulanık Karar Destek Sistemi Geliştirme ve Bir Uygulama", Doktora Tezi, İstanbul Teknik Üniversitesi, Fen Bilimleri Enstitüsü, 2010

[10] E. Yılmaz, "İş Zekası Araçları ve Ormancılı", İstanbul Üniversitesi Orman Fakültesi Dergisi, 55, 1, pp. 135-146, 2005.

[11] S. Pazarçeviren, Ü. Zor, F. Gürbüz, "İş Zekâsı: Kavramsal Çerçeve, Bileşenler ve İşleyiş", Siyaset, Ekonomi ve Yönetim Araştırmaları Dergisi, 3 , 1, pp. 75-91, 2015.

[12] N.H. Rasmussen, P.S. Goldy, P.O. Solli, "Financial Business Intellegence", John Walley \& Sons, 2002.

[13] C. Vercellis, "Business Intelligence: Data Mining and Optimization for Decision Making", John Wiley \& Sons, 3-4, 2009.

[14] B. Tok, "Karar Destek Sistemleri ve Finans Sektöründeki Uygulamaları", Yüksek Lisans Tezi, İstanbul Teknik Üniversitesi, Fen Bilimleri Enstitüsü, 2015.

[15] V. Arslan, G. Yılmaz, "Karar Desek Sistemlerinin Kullanımı İçin Uygun Bir Model Geliştirilmesi", Havacılık ve Uzay Teknolojileri Dergisi, 4, 4, pp. 75-82, 2010.

[16] B. Doğan, B. Erol, A. Buldu, "Sigortacılık Sektöründe Müşteri İlişkileri Yönetimi İçin Birliktelik Kuralı Kullanılması", Marmara Fen Bilimleri Dergisi, 3, pp. 105-114, 2014.

[17] P. Lee, "Use Of Data Mining In Business Analytics To Support Business Competitiveness", Review of Business Information Systems- Second Quarter 2013, 17, 2, 2013.

[18] A. Koyuncugil, N. Özgülbaş, "Veri Madenciliği: Tıp ve Sağlık Hizmetlerinde Kullanımı ve Uygulamaları", Bilişim Teknolojileri Dergisi, 2, 2, pp. 21-32, 2009.

[19] Özmen S., Şen B., "Veri Madenciliğinde Regresyon Yöntemleri ile Doğalgaz Sektöründe Talep - Tüketim Analizi”, Akademik Bilişim 2013, Antalya, 2013, pp. 887-891.

[20] Koyuncugil, A.S., Özgülbaş, N., ” Veri Madenciliği: Tıp ve Sağlı Hizmetlerinde Kullanımı ve Uygulamaları”, Bilişim Teknolojileri Dergisi, 2, $2,2009$.

[21] B. K. Mishra, D. Hazra, K. Tarannum and M. Kumar, "Business Intelligence using Data Mining techniques and Business Analytics," 2016 International Conference System Modeling \& Advancement in Research Trends (SMART), Moradabad, 2016, pp. 84-89.

[22] T. Guarda, M. Santos, F. Pinto, M. Augusto, C. Silva, "Business Intelligence as a Competitive Advantage for SMEs", International Journal of Trade, Economics and Finance. 187-190, 2013

[23] T. Kumar, G. Sravanthi, D. Deepthi, "Competitive Advantage through Business Intelligence for E-Commerce", International Journal of Computer \& Organization Trends, 43-48, 3, 6. 2013. 


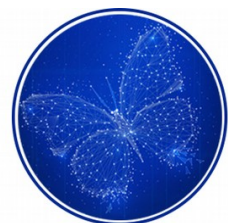

artificial intelligence studies
ARTIFICIAL INTELLIGENCE STUDIES

YAPAY ZEKA CCALISSMALARI

2018, 4(1): 8-25

www.aistudies.org

[24] M. Atıcı, Gelecek nesil iş zekası uygulamaları, http://www.itnetwork.com.tr/gelecek-nesil-is-zekasi-uygulamalari-nelerdir/, Erişim tarihi: 29/04/2015].

[25] M.K. Gözcü, "Hastane Bilgi Yönetim Sistemlerinde İş Zekasi Uygulaması", Yüksek Lisans Tezi, Başkent Üniversitesi, Fen Bilimleri Enstitüsü, 2015 .

[26] D. Gündüz, "İ̧̧ Zekasi Uygulamalari ve Pazar Sepeti Analizi", Yüksek Lisans Tezi, İstanbul Üniversitesi, Fen Bilimleri Enstitüsü, 2015.

[27] S. Erpolat, "Otomobil Yetkili Servislerinde Birliktelik Kurallarının Belirlenmesinde Apriori ve FP-Growth Algoritmalarının Karşılaştırılması", Anadolu Üniversitesi Sosyal Bilimler Dergisi, 12, 1, pp. 151-166, 2012.

[28] M. Alaeddinoğlu, T. Aydın, D. Dal, "Birliktelik Kuralları İle Mekânsal-Zamansal Veri Madenciliği", Erzincan Üniversitesi Fen Bilimleri Enstitüsü Dergisi, 5, 2, pp. 191-212, 2012.

[29] A. Bilgi, "Müşteri İlişkileri Yönetiminde İş Zekasi Uygulamalari", Yüksek Lisans Tezi, Anadolu Üniversitesi, Fen Bilimleri Enstitüsü, 2015.

[30] J. M. V. García, B. H. D. Pinzón, Beatriz Helena, "Key success factors to business intelligence solution implementation”, Journal of Intelligence Studies in Business, 7, pp. 48-69, 2017.

[31] H. G. Hwang, C. Y. Ku, D. V. Yen, C. C. Cheng, "Critical factors influencing the adoption of data warehouse technology: A study of the banking industry in Taiwan”, Decision Support Systems, 37, 1, pp.1-21, 2004.

[32] B. H. Wixom, H. J. Watson, “An empirical investigation of the factors affecting data warehouse success", MIS Quarterly, 25, 1, pp. 17-41, 2001.

[33] U. B. Qushem, A. M. Zeki, A. Abubakar, "Successful Business Intelligence System for SME: An Analytical Study in Malaysia", IOP Conference Series: Materials Science and Engineering, 226, 1, pp. 1-9, 2017.

[34] H. Singh, "Implementation Benefit to Business Intelligence using Data MiningTechniques", International Journal of Computing \& Business Research, 2012.

[35] M. Miskuf, I. Zolotova, "Application of Business Intelligence Solutions on Manufacturing Data", IEEE 13th International Symposium on Applied Machine Intelligence and Informatics, Slovakya, 15-18 Ocak, 2015.

[36] M. A. Khan, W. Gharibi and S. K. Pradhan, "Data mining techniques for business intelligence in educational system: A case mining," 2014 World Congress on Computer Applications and Information Systems (WCCAIS), Hammamet, 2014, pp. 1-5.

[37] M. Hudek, Z. Savic, D. Radovic, “A Business Intelligence System for School Management on Local Government Level”, Tehnički vjesnik 24, 3 , 821-828, 2017

[38] Y. Wang, "Application of budget system based on business intelligence," 2016 7th IEEE International Conference on Software Engineering and Service Science (ICSESS), Beijing, 2016, pp. 808-812.

[39] P. Keerin, "Development of business intelligence solution for personnel administration," 2016 Second Asian Conference on Defence Technology (ACDT), Chiang Mai, 2016, pp. 139-144. 